\title{
The effect of sodium chloride substitution with potassium chloride on texture profile and microstructure of Halloumi cheese
}

\author{
M. M. Ayyash, ${ }^{\star}$ F. Sherkat, † P. Francis,‡ R. P. W. Williams,§ and N. P. Shah ${ }^{\star 1}$ \\ *School of Biomedical and Health Sciences, Faculty of Health, Engineering and Science, Victoria University, Werribee Campus, PO Box 14428, \\ Melbourne, Victoria 8001, Australia \\ †School of Applied Sciences, Food Science, RMIT University, PO Box 2476, Melbourne, Victoria 3001, Australia \\ ‡Department of Applied Physics, RMIT University, Melbourne, Victoria 3000, Australia \\ $\S$ Commonwealth Scientific and Industrial Research Organization (CSIRO) Food and Nutritional Sciences, Werribee, Victoria 3030, Australia
}

\begin{abstract}
The effect of partial substitution of $\mathrm{NaCl}$ with $\mathrm{KCl}$ on texture profile and microstructure of Halloumi cheese was investigated. Four batches of Halloumi cheese were made and kept in 4 different brine solutions (18\%, wt/wt), including A) $\mathrm{NaCl}$ only, B) $3 \mathrm{NaCl}: 1 \mathrm{KCl}, \mathrm{C}$ ) $1 \mathrm{NaCl}: 1 \mathrm{KCl}$, and D) $1 \mathrm{NaCl}: 3 \mathrm{KCl}$ and then stored at $4^{\circ} \mathrm{C}$ for $56 \mathrm{~d}$. The texture profile was analyzed using an Instron universal machine, whereas an environmental scanning electron microscope was used to investigate the effect of $\mathrm{NaCl}$ substitution on the microstructure of cheeses. No significant difference was found in hardness, cohesiveness, adhesiveness, and gumminess among experimental cheeses at the same storage day. Hardness, cohesiveness, and gumminess decreased significantly during storage period with the same salt treatment, whereas adhesiveness significantly increased. Environmental scanning electron microscope micrographs showed a compact and closed texture for cheeses at the same storage period. The microstructure of all cheeses became more closed and compact with storage period. Calcium content negatively correlated with hardness and $\mathrm{Na}$ and $\mathrm{K}$ contents during storage with the same salt treatment.
\end{abstract}

Key words: Halloumi cheese, texture profile, environmental scanning electron microscope, microstructure

\section{INTRODUCTION}

Halloumi cheese is a traditional Cyprus cheese made from ovine, caprine, and bovine milk (Anifantakis and Kaminarides, 1983). Recently, Halloumi cheese has become popular in the Middle Eastern countries (Kaminarides et al., 2007) and has gained an international acceptance in the European Union and the United States (Papademas and Robinson, 2001; Tamime, 2006).

Received May 5, 2010.

Accepted October 12, 2010.

${ }^{1}$ Corresponding author: Nagendra.Shah@vu.edu.au
Normally, its color varies from whitish to yellowish, depending on the milk source (Robinson, 1991). Heating Halloumi pieces at 90 to $95^{\circ} \mathrm{C}$ in heat-deproteinated whey for $30 \mathrm{~min}$ is considered a distinctive processing step during cheese manufacturing. Halloumi cheese is usually stored in 12 to $18 \%$ brine solution at $4^{\circ} \mathrm{C}$ (Abd El-Salam and Alichanidis, 2004). Although salt influences cheese characteristics, including proteolysis, lipolysis, texture profile, and flavor, and traditionally has been used as a preservative (Guinee and Fox, 2004), it causes serious health issues for consumers. A high positive association between $\mathrm{NaCl}$ intake and hypertension has been reported (Forshee, 2008). Similarly, a positive correlation has been found between salt intake and osteoporosis and kidney stones (Massey and Whiting, 1995; Massey, 2005; Heaney, 2006). The dietary Na intake of $\mathrm{NaCl}$ among people in developed countries is 10 to 35 times higher than the recommended daily intake of $2.5 \mathrm{~g}$ of sodium (Shank et al., 1982; Kaplan, 2000; Guinee, 2004). Hence, there has been a trend to decrease $\mathrm{NaCl}$ content in food (Reddy and Marth, 1991; Guinee, 2004); however, a reduction in salt adversely affects the characteristics of cheeses and other foods (Petik, 1987; Katsiari and Voutsinas, 1994a; Johnson et al., 2009). Numerous studies have been carried out to decrease $\mathrm{Na}$ content in cheeses by substituting $\mathrm{NaCl}$ with $\mathrm{KCl}$ (Zorrilla and Rubiolo, 1994; Katsiari et al., 1998; Sihufe et al., 2006). An excess of dietary intake of $\mathrm{KCl}$ has no undesirable effect on people with $\mathrm{Na}$ induced hypertension (Lemann et al., 1993).

In general, texture profile and microstructure of cheeses are important parameters. Salting of cheeses affects the texture profile and microstructure directly or indirectly. Several studies have investigated the effect of partial substitution of $\mathrm{NaCl}$ with $\mathrm{KCl}$ on the texture profile of cheeses. Fitzgerald and Buckley (1985) reported that the texture profile of Cheddar cheese made with a $\mathrm{NaCl}$ and $\mathrm{KCl}$ mixture was similar compared with that of the control (only $\mathrm{NaCl}$ ). Katsiari et al. $(1997,1998)$ reported similar results for Feta and Kefalograviera cheeses, respectively. However, information 
is lacking on the texture profile and microstructure of Halloumi cheese as a result of reduction in the salt level. In this study, our objectives were to investigate the effect of partial substitution of $\mathrm{NaCl}$ with $\mathrm{KCl}$ on the texture profile and microstructure of Halloumi cheese during storage at $4^{\circ} \mathrm{C}$ for $56 \mathrm{~d}$.

\section{MATERIALS AND METHODS}

\section{Cheesemaking}

Homogenized and pasteurized full fat bovine milk (3\% fat) was purchased from a local dairy plant (Melbourne, Victoria, Australia). Halloumi cheese was manufactured according to Alichanidis and Polychroniadou (2008) with some modifications. In brief, milk (20 L) was tempered to $37^{\circ} \mathrm{C}$, and starter culture consisting of Streptococcus thermophilus and Lactobacillus delbrueckii ssp. bulgaricus was added according to manufacturer instructions (Chr. Hansen, Bayswater, Victoria, Australia). After $30 \mathrm{~min}$ of ripening, $5 \mathrm{~mL}$ of chymosin (Chy-Max, Chr. Hansen) diluted in $100 \mathrm{~mL}$ of distilled water was added to milk, followed by mixing for $2 \mathrm{~min}$. The milk coagulated in 35 min and the curd was cut into $1 \mathrm{~cm}^{3}$ cubes and let stand for $10 \mathrm{~min}$, followed by stirring for $15 \mathrm{~min}$ at $37^{\circ} \mathrm{C}$. The curd was transferred into cheesecloth and whey was drained. The curd was pressed for $60 \mathrm{~min}$; each $1 \mathrm{~kg}$ of curd was pressed with a $60-\mathrm{kg}$ weight. Pressed curd was cut into $6 \times 6 \times 3$-cm loaves and heated in heat-deproteinized whey at 90 to $95^{\circ} \mathrm{C}$ for $30 \mathrm{~min}$. Cheeses were randomly distributed into 4 different brine solutions (18\%, wt/wt) made from different $\mathrm{NaCl}: \mathrm{KCl}$ ratios as follows: $\mathrm{NaCl}$ only (A; control); $3 \mathrm{NaCl}: 1 \mathrm{KCl}(\mathrm{B}) ; 1 \mathrm{NaCl}: 1 \mathrm{KCl}(\mathrm{C})$; and $1 \mathrm{NaCl}: 3 \mathrm{KCl}(\mathrm{D})$. Cheeses in brine solutions were stored at $4^{\circ} \mathrm{C}$ and samples were taken for determination of texture profile, microstructure, and $\mathrm{Na}, \mathrm{K}$, and $\mathrm{Ca}$ contents at $0,14,28,42$, and $56 \mathrm{~d}$ of storage. Experimental cheeses were replicated 4 times.

\section{Chemical Composition}

Moisture was determined by the oven-drying method at $102^{\circ} \mathrm{C}$, fat by the Babcock method, protein by the Kjeldahl method, and ash by the muffle furnace method according to the AOAC methods (AOAC International, $1995)$. For $\mathrm{pH}$ measurement, grated cheese $(20 \mathrm{~g})$ was macerated with $20 \mathrm{~mL}$ of distilled water, and the $\mathrm{pH}$ of the resultant slurry was measured using a calibrated digital $\mathrm{pH}$ meter (MeterLab, Pacific Laboratory Products, Blackburn, Victoria, Australia). Analyses were carried out in quadruplicate.

\section{Texture Profile Analysis}

Texture profile (hardness, cohesiveness, adhesiveness, and gumminess) was analyzed according to Bhaskaracharya and Shah (1999) with some modifications. Cylinders of $25 \times 20$-mm cheeses were cut from Halloumi cheese blocks at the center. Specimens were kept in a refrigerator at $4^{\circ} \mathrm{C}$ overnight, followed by determination of texture profile. Hardness, cohesiveness, adhesiveness, and gumminess were measured using an Instron universal testing machine (model 5564; Instron Ltd., London, UK) based on the principle described by Pons and Fiszman (1996). The samples were compressed to $50 \%$ of their heights using a $100-\mathrm{N}$ load cell with a flat plunger and the crosshead movement was adjusted to $50 \mathrm{~mm} / \mathrm{min}$. Double compression was achieved and the data were collected using Merline software. Analyses were carried out in quadruplicate.

\section{Microstructure by Environmental Scanning Electron Microscopy}

Experimental cheese specimens were imaged by FEI Quanta environmental scanning electron microscopy (ESEM; Philips Electron Optics, Eindhoven, the Netherlands) using ESEM mode. Images were taken at accelerating voltage at $30 \mathrm{kV}$ under $0.47 \mathrm{kPa}$ pressure and $1,200 \times$ magnification at $4^{\circ} \mathrm{C}$. Specimens were not conductivity coated before imaging.

\section{Determination of $\mathrm{Na}, \mathrm{K}$, and $\mathrm{Ca}$ Contents by Multitype Inductively Coupled Plasma Atomic Emission Spectrometry}

Sodium, potassium, and calcium contents in cheeses were analyzed by multitype inductively coupled plasma atomic emission spectrometry (ICPE-9000; Shimadzu Scientific Instruments (Oceania) Pty Ltd, Rydalmere, NSW, Australia) according to Cichoscki et al. (2002) with some modifications. In brief, after the ash determination of cheese samples, an aliquot (approximately $0.5 \mathrm{~g}$ ) was dissolved with $10 \mathrm{~mL}$ of $1 N \mathrm{HNO}_{3}$ and kept frozen $\left(-20^{\circ} \mathrm{C}\right)$ until analyzed with the ICPE-9000. Samples were diluted 100 times, followed by filtration using $0.45 \mu \mathrm{m}$ micro-syringes (Millex, Millipore, Bedford, MA) before direct injection into the ICPE-9000. The ICPE-9000 consisted of an ASC-6100 autosampler, hydride generator HVG-ICP, hydrofluoric acid sample injection system HFS-2, low-temperature thermostatic chamber NCB-1200, and software package ICPE-9000. To calculate $\mathrm{Na}, \mathrm{K}$, and $\mathrm{Ca}$ concentrations in samples, a standard curve consisting of the 3 elements was pre- 
Table 1. Moisture, protein, fat, ash contents (\% on wet basis), and $\mathrm{pH}$ value of Halloumi cheeses kept in brine solutions with 4 levels of $\mathrm{NaCl}$ and $\mathrm{NaCl} / \mathrm{KCl}$ mixtures at 0 d of storage ${ }^{1}$

\begin{tabular}{lccccc}
\hline $\begin{array}{l}\text { Salt } \\
\text { treatment }\end{array}$ & & & & & \\
& Moisture (\%) & Protein (\%) & Fat $(\%)$ & Ash (\%) & pH \\
\hline A & $51.50 \pm 0.8^{\mathrm{a}}$ & $21.41 \pm 0.59^{\mathrm{a}}$ & $21.75 \pm 1.67^{\mathrm{a}}$ & $4.55 \pm 0.50^{\mathrm{a}}$ & $5.27 \pm 0.04^{\mathrm{b}}$ \\
$\mathrm{B}$ & $50.75 \pm 0.27^{\mathrm{a}}$ & $20.64 \pm 0.29^{\mathrm{a}}$ & $22.80 \pm 1.49^{\mathrm{a}}$ & $4.53 \pm 0.36^{\mathrm{a}}$ & $5.33 \pm 0.03^{\mathrm{ab}}$ \\
$\mathrm{C}$ & $50.48 \pm 0.60^{\mathrm{a}}$ & $20.13 \pm 0.44^{\mathrm{a}}$ & $21.30 \pm 1.28^{\mathrm{a}}$ & $3.86 \pm 0.33^{\mathrm{a}}$ & $5.38 \pm 0.07^{\mathrm{ab}}$ \\
$\mathrm{D}$ & $50.21 \pm 0.49^{\mathrm{a}}$ & $20.11 \pm 0.88^{\mathrm{a}}$ & $19.33 \pm 0.98^{\mathrm{a}}$ & $4.48 \pm 0.66^{\mathrm{a}}$ & $5.48 \pm 0.12^{\mathrm{a}}$ \\
\hline
\end{tabular}

${ }^{\mathrm{a}, \mathrm{b}}$ Means in each column with the same letter did not differ significantly $(P>0.05)$.

${ }^{1}$ Results are expressed as mean values $\pm \mathrm{SE}$ of 4 trials.

${ }^{2} \mathrm{~A}=\mathrm{NaCl}$ only (control); $\mathrm{B}=3 \mathrm{NaCl}: 1 \mathrm{KCl}$ (wt/wt); $\mathrm{C}=1 \mathrm{NaCl}: 1 \mathrm{KCl}$ (wt/wt); $\mathrm{D}=1 \mathrm{NaCl}: 3 \mathrm{KCl}$ (wt/wt).

pared at $1,10,20,30$, and $40 \mathrm{mg} / \mathrm{kg}$. Analyses were carried out in quadruplicate.

\section{Statistical Analysis}

One-way ANOVA was used to test differences among 4 experimental cheeses for each salt treatment or sampling day and significance was tested at $P<0.05$. Pearson correlation was measured at $P<0.05$ between all variables. Data were analyzed using SAS software version 9.2 (SAS Institute, 2008).

\section{RESULTS AND DISCUSSION}

\section{Chemical Composition}

Moisture, protein, fat, and ash contents and the $\mathrm{pH}$ value of experimental cheeses at $0 \mathrm{~d}$ are shown in Table
1. As shown in the table, salt treatment did not affect $(P>0.05)$ the chemical composition of Halloumi cheese at $0 \mathrm{~d}$ of storage. Moisture, protein, ash, and fat contents showed no significant $(P>0.05)$ differences among experimental cheeses. This suggests that $\mathrm{KCl}$ may have the same effect as $\mathrm{NaCl}$ on Halloumi cheese. These findings are in accordance with those of Katsiari et al. $(1997,1998)$ and Reddy and Marth (1993) for Feta, Kefalograviera, and Cheddar cheeses, respectively.

\section{Texture Profile Analysis}

Hardness, cohesiveness, adhesiveness, and gumminess results of Halloumi cheeses kept in $\mathrm{NaCl}$ only (A) and $\mathrm{NaCl}$ and $\mathrm{KCl}$ mixtures (B, C, and D) are presented in Table 2. No significant $(P>0.05)$ difference was found in hardness, cohesiveness, adhesiveness, and

Table 2. Texture profile of Halloumi cheeses kept in 4 levels of $\mathrm{NaCl}$ and $\mathrm{KCl}$ during storage at $4^{\circ} \mathrm{C}^{1}$

\begin{tabular}{|c|c|c|c|c|c|}
\hline $\begin{array}{l}\text { Storage } \\
\text { time }\end{array}$ & $\begin{array}{l}\text { Salt } \\
\text { treatment }^{2}\end{array}$ & Hardness & Cohesiveness & Adhesiveness & Gumminess \\
\hline \multirow[t]{4}{*}{ d 0} & A & $28.200 \pm 1.774^{\mathrm{a}}$ & $0.324 \pm 0.013^{\mathrm{a}}$ & $0.146 \pm 0.009^{\mathrm{a}}$ & $9.211 \pm 0.984^{\mathrm{a}}$ \\
\hline & B & $32.378 \pm 1.266^{\mathrm{a}}$ & $0.345 \pm 0.048^{\mathrm{a}}$ & $0.113 \pm 0.010^{\mathrm{a}}$ & $11.150 \pm 1.515^{\mathrm{a}}$ \\
\hline & $\mathrm{C}$ & $27.840 \pm 2.693^{\mathrm{a}}$ & $0.379 \pm 0.018^{\mathrm{a}}$ & $0.167 \pm 0.060^{\mathrm{a}}$ & $10.580 \pm 1.228^{\mathrm{a}}$ \\
\hline & $\mathrm{D}$ & $27.540 \pm 3.304^{\mathrm{a}}$ & $0.375 \pm 0.046^{\mathrm{a}}$ & $0.174 \pm 0.061^{\mathrm{a}}$ & $10.509 \pm 2.031^{\mathrm{a}}$ \\
\hline \multirow[t]{4}{*}{ d 14} & $\mathrm{~A}$ & $49.733 \pm 8.882^{\mathrm{a}}$ & $0.309 \pm 0.030^{\mathrm{a}}$ & $0.149 \pm 0.062^{\mathrm{a}}$ & $15.312 \pm 1.042^{\mathrm{a}}$ \\
\hline & $\mathrm{B}$ & $43.785 \pm 5.904^{\mathrm{a}}$ & $0.265 \pm 0.047^{\mathrm{a}}$ & $0.233 \pm 0.056^{\mathrm{a}}$ & $11.411 \pm 2.145^{\mathrm{a}}$ \\
\hline & $\mathrm{C}$ & $43.612 \pm 4.775^{\mathrm{a}}$ & $0.250 \pm 0.026^{\mathrm{a}}$ & $0.129 \pm 0.060^{\mathrm{a}}$ & $10.938 \pm 1.505^{\mathrm{a}}$ \\
\hline & $\mathrm{D}$ & $41.410 \pm 2.162^{\mathrm{a}}$ & $0.241 \pm 0.045^{\mathrm{a}}$ & $0.157 \pm 0.083^{\mathrm{a}}$ & $10.113 \pm 2.060^{\mathrm{a}}$ \\
\hline \multirow[t]{4}{*}{ d 28} & A & $40.160 \pm 8.813^{\mathrm{a}}$ & $0.343 \pm 0.022^{\mathrm{a}}$ & $0.113 \pm 0.037^{\mathrm{a}}$ & $8.343 \pm 3.927^{\mathrm{a}}$ \\
\hline & $\mathrm{B}$ & $25.908 \pm 7.528^{\mathrm{a}}$ & $0.286 \pm 0.020^{\mathrm{b}}$ & $0.126 \pm 0.038^{\mathrm{a}}$ & $7.129 \pm 1.650^{\mathrm{a}}$ \\
\hline & $\mathrm{C}$ & $29.158 \pm 5.403^{\mathrm{a}}$ & $0.229 \pm 0.026^{\mathrm{b}}$ & $0.135 \pm 0.053^{\mathrm{a}}$ & $7.054 \pm 1.828^{\mathrm{a}}$ \\
\hline & $\mathrm{D}$ & $26.612 \pm 4.783^{\mathrm{a}}$ & $0.280 \pm 0.056^{\mathrm{ab}}$ & $0.168 \pm 0.050^{\mathrm{a}}$ & $7.758 \pm 2.100^{\mathrm{a}}$ \\
\hline \multirow[t]{4}{*}{ d 42} & $\mathrm{~A}$ & $25.759 \pm 7.401^{\mathrm{a}}$ & $0.244 \pm 0.044^{\mathrm{a}}$ & $0.436 \pm 0.190^{\mathrm{a}}$ & $6.044 \pm 0.691^{\mathrm{a}}$ \\
\hline & B & $17.357 \pm 4.092^{\mathrm{a}}$ & $0.203 \pm 0.024^{\mathrm{a}}$ & $0.199 \pm 0.133^{\mathrm{a}}$ & $3.642 \pm 1.017^{\mathrm{a}}$ \\
\hline & $\mathrm{C}$ & $16.462 \pm 3.192^{\mathrm{a}}$ & $0.238 \pm 0.053^{\mathrm{a}}$ & $0.372 \pm 0.095^{\mathrm{a}}$ & $3.895 \pm 0.939^{\mathrm{a}}$ \\
\hline & $\mathrm{D}$ & $19.505 \pm 4.488^{\mathrm{a}}$ & $0.209 \pm 0.034^{\mathrm{a}}$ & $0.284 \pm 0.137^{\mathrm{a}}$ & $3.868 \pm 0.737^{\mathrm{a}}$ \\
\hline \multirow[t]{4}{*}{ d 56} & A & $22.443 \pm 7.256^{\mathrm{a}}$ & $0.310 \pm 0.062^{\mathrm{a}}$ & $0.269 \pm 0.129^{\mathrm{a}}$ & $4.493 \pm 0.701^{\mathrm{a}}$ \\
\hline & B & $14.411 \pm 1.023^{\mathrm{a}}$ & $0.266 \pm 0.064^{\mathrm{a}}$ & $0.344 \pm 0.091^{\mathrm{a}}$ & $3.993 \pm 2.163^{\mathrm{a}}$ \\
\hline & $\mathrm{C}$ & $13.315 \pm 2.775^{\mathrm{a}}$ & $0.302 \pm 0.029^{\mathrm{a}}$ & $0.260 \pm 0.119^{\mathrm{a}}$ & $3.912 \pm 0.644^{\mathrm{a}}$ \\
\hline & $\mathrm{D}$ & $10.640 \pm 2.374^{\mathrm{a}}$ & $0.261 \pm 0.025^{\mathrm{a}}$ & $0.426 \pm 0.065^{\mathrm{a}}$ & $2.762 \pm 0.570^{\mathrm{a}}$ \\
\hline
\end{tabular}

a,b Means in each column and at the same storage time with the same letter did not differ significantly $(P>$ $0.05)$.

${ }^{1}$ Results are expressed as mean values $\pm \mathrm{SE}$ of 4 trials.

${ }^{2} \mathrm{~A}=\mathrm{NaCl}$ only (control); $\mathrm{B}=3 \mathrm{NaCl}: 1 \mathrm{KCl}$ (wt/wt); $\mathrm{C}=1 \mathrm{NaCl}: 1 \mathrm{KCl}$ (wt/wt); D = 1NaCl:3KCl (wt/wt). 
a

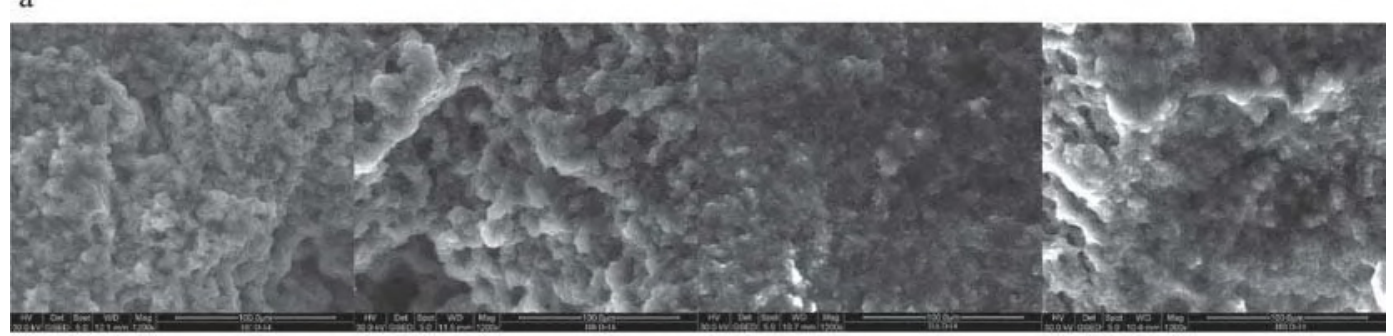

b

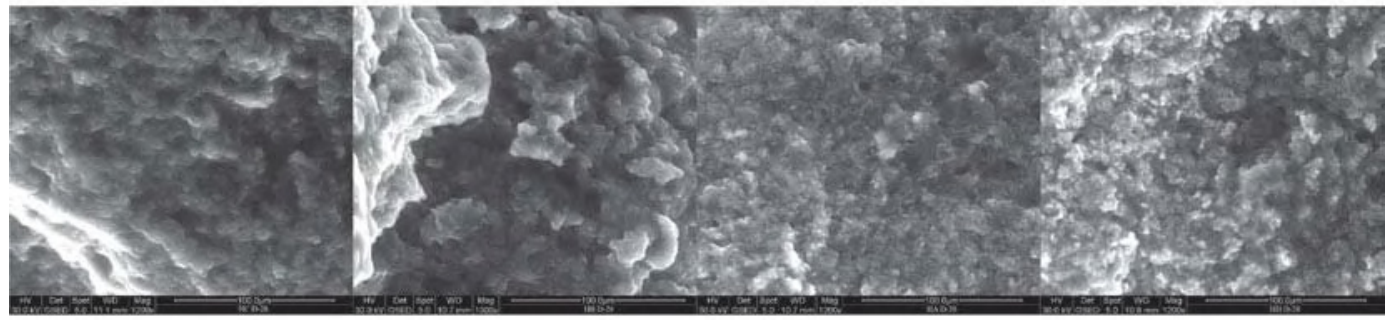

c

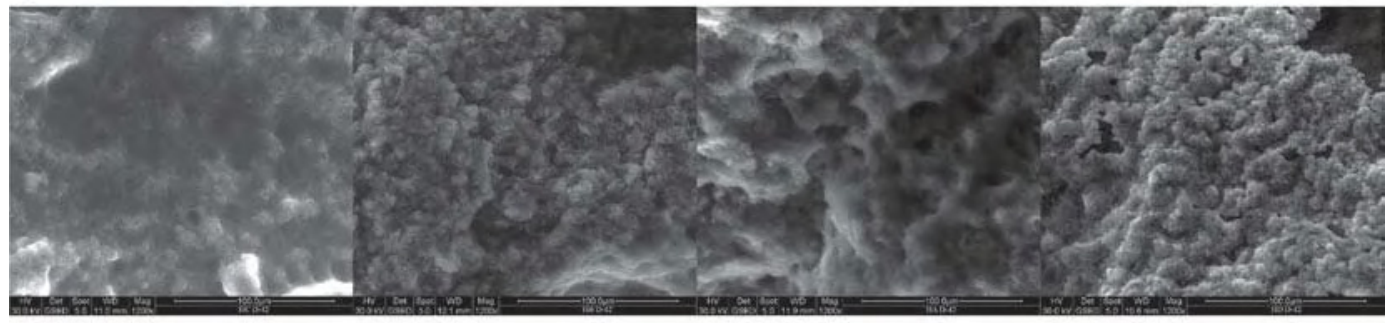

d

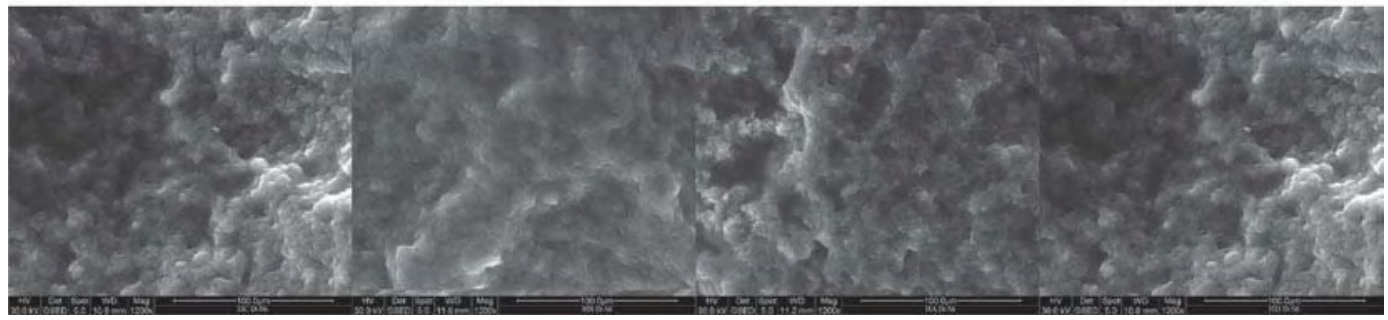

Figure 1. Environmental scanning electron micrograph of Halloumi cheese made with $\mathrm{NaCl}$ only (A; control); $3 \mathrm{NaCl}: 1 \mathrm{KCl}(\mathrm{B}$; wt/wt); $1 \mathrm{NaCl}: 1 \mathrm{KCl}(\mathrm{C}$; wt/wt); and $1 \mathrm{NaCl}: 3 \mathrm{KCl}(\mathrm{D}$; wt/wt) at 14 (a), 28 (b), 42 (c), and 56 (d) d of storage. Treatments A to D are shown from left to right, respectively.

gumminess among experimental cheeses at the same storage period. This suggests that $\mathrm{KCl}$ may have the same role in Halloumi cheese as does $\mathrm{NaCl}$, up to $75 \%$ replacement (Taylor, 1983). These observations are in agreement with those of Katsiari et al. $(1997,1998)$ and Fitzgerald and Buckley (1985) for Feta, Kefalograviera, and Cheddar cheeses, respectively.

For the same salt treatment, ANOVA showed that hardness and gumminess decreased significantly $(P<$ $0.05)$ after $2 \mathrm{wk}$ of storage. These findings are in accordance with those of Katsiari and Voutsinas (1994b), Katsiari et al. (1998), and Zaki (1990) for Kefalograviera and Domiati cheeses. This trend may be attributed to 2 reasons. First, the decrease in Ca of $65 \%$ (from approximately $0.43 \mathrm{mg} / 100 \mathrm{~g}$ at $\mathrm{d} 0$ to approximately $0.15 \mathrm{mg} / 100 \mathrm{~g}$ at d 56) during storage, led to a reduction in cross-linkages between caseins. The Ca decrease, attributed to $\mathrm{Ca}$ ion diffusion in brine solution, may cause a decrease in colloidal Ca, which, in turn, increases cheese softening. Second, the increase in proteoylsis (unpublished data) during storage hydrolyzed protein and softened the cheese matrix (Guinee et al., 2002; Joshi et al., 2003).

The ANOVA showed that adhesiveness increased $(P$ $<0.05)$, whereas cohesiveness decreased $(P<0.05)$ at the end of the storage period compared with the 
Table 3. Pearson correlations of $\mathrm{Na}, \mathrm{K}$, and $\mathrm{Ca}$ with the texture profile for the same salt treatment ${ }^{1}$

\begin{tabular}{|c|c|c|c|c|c|}
\hline Element & $\begin{array}{l}\text { Salt } \\
\text { treatment }^{2}\end{array}$ & Hardness & Cohesiveness & Adhesiveness & Gumminess \\
\hline \multirow[t]{7}{*}{$\mathrm{Na}$} & $\mathrm{A}$ & $\begin{array}{r}-0.1793 \\
(0.5225)\end{array}$ & $\begin{array}{c}-0.3245 \\
(0.2381)\end{array}$ & $\begin{array}{c}0.7377 \\
(0.0017)\end{array}$ & $\begin{array}{r}-0.3226 \\
(0.2410)\end{array}$ \\
\hline & B & -0.6375 & -0.4530 & 0.4252 & -0.7591 \\
\hline & & $(0.0044)$ & $(0.0591)$ & $(0.0786)$ & $(0.0003)$ \\
\hline & $\mathrm{C}$ & -0.6023 & -0.3467 & 0.5011 & -0.7479 \\
\hline & & $(0.0050)$ & $(0.1342)$ & $(0.0244)$ & $(0.0001)$ \\
\hline & $\mathrm{D}$ & -0.5909 & -0.5929 & 0.4058 & -0.7539 \\
\hline & & $(0.0204)$ & $(0.0198)$ & $(0.1334)$ & $(0.0012)$ \\
\hline \multirow[t]{8}{*}{$\mathrm{K}$} & A & -0.5076 & -0.3171 & 0.6234 & -0.6179 \\
\hline & & $(0.0534)$ & $(0.2494)$ & $(0.0130)$ & $(0.0141)$ \\
\hline & B & 0.0908 & -0.3151 & 0.3251 & -0.1211 \\
\hline & & $(0.7201)$ & $(0.2029)$ & $(0.1880)$ & $(0.6320)$ \\
\hline & $\mathrm{C}$ & -0.6743 & -0.2793 & 0.5082 & -0.7781 \\
\hline & & $(0.0011)$ & $(0.2330)$ & $(0.0221)$ & $(<0.0001)$ \\
\hline & $\mathrm{D}$ & -0.6663 & -0.4842 & 0.4065 & -0.7132 \\
\hline & & $(0.0067)$ & $(0.0674)$ & $(0.1327)$ & $(0.0028)$ \\
\hline \multirow[t]{8}{*}{$\mathrm{Ca}$} & A & -0.0870 & -0.0231 & -0.5906 & -0.0948 \\
\hline & & $(0.7579)$ & $(0.9348)$ & $(0.0205)$ & (0.7369) \\
\hline & B & 0.3984 & 0.5347 & -0.4468 & 0.6485 \\
\hline & & $(0.1015)$ & $(0.0222)$ & $(0.0630)$ & $(0.0036)$ \\
\hline & $\mathrm{C}$ & 0.3914 & 0.4859 & -0.2720 & 0.6202 \\
\hline & & $(0.0879)$ & $(0.0298)$ & $(0.2460)$ & $(0.0035)$ \\
\hline & $\mathrm{D}$ & 0.2565 & 0.6464 & -0.2092 & 0.5528 \\
\hline & & $(0.3562)$ & $(0.0092)$ & $(0.4542)$ & $(0.0326)$ \\
\hline
\end{tabular}

${ }^{1}$ Results are expressed as correlation coefficients ( $P$-values in parentheses).

${ }^{2}$ Salt treatment: $\mathrm{A}=\mathrm{NaCl}$ only $($ control); $\mathrm{B}=3 \mathrm{NaCl}: 1 \mathrm{KCl}(\mathrm{wt} / \mathrm{wt}) ; \mathrm{C}=1 \mathrm{NaCl}: 1 \mathrm{KCl}(\mathrm{wt} / \mathrm{wt}) ; \mathrm{D}=$ $1 \mathrm{NaCl}: 3 \mathrm{KCl}(\mathrm{wt} / \mathrm{wt})$.

adhesiveness and cohesiveness at $\mathrm{d} 0$ for the same salt treatment. These observations are in agreement with those of Bhaskaracharya and Shah (2000), which were similar for Mozzarella cheese. The increase in adhesiveness may be due to the increase in proteolysis during storage, which, in turn, increased small peptides in the serum phase and, thus, increased adhesiveness (Bhaskaracharya and Shah, 2000). The decrease $(P<$ $0.05)$ in cohesiveness may be due to the decrease in Ca and increase in proteolysis (Bhaskaracharya and Shah, 2000).

\section{Microstructure}

The ESEM images of experimental cheeses at 14, 28, 42, and $56 \mathrm{~d}$ storage are shown in Figure 1 (A, B, C, and $\mathrm{D}$, respectively). Micrographs show compact and closed structures with small voids in all experimental cheeses. This suggests that microstructure of Halloumi cheeses kept in various $\mathrm{NaCl}$ and $\mathrm{KCl}$ mixtures did not differ compared with that of the control. However, voids disappeared slightly with prolonged storage and this was more obvious in cheeses stored between d 14 and 56 (Figure 1A and 1D, respectively) as compared with those stored between periods close together, such as d 42 and 56 (Figure 1C and 1D, respectively). This may be attributed to a decrease in moisture content
(Ayyash and Shah, 2010) and an increase in proteolysis. It has been reported that proteolysis in cheese produces small peptides that are soluble in the serum phase of cheese (Fox and McSweeney, 1996; Upadhyay et al., 2004). Therefore, we believe that the increase in small peptides in Halloumi cheeses and the decrease in moisture content increased the compactness of Halloumi cheese texture.

\section{Correlations}

Pearson correlation coefficients between $\mathrm{Na}$, K, and $\mathrm{Ca}$ with texture profile parameters are presented in Table 3. In general, Ca had a positive correlation with hardness, cohesiveness, and gumminess, whereas a negative correlation was shown with adhesiveness for the $\mathrm{NaCl}$ and $\mathrm{KCl}$ mixture treatments. This supports the observation that the decrease in hardness can be attributed to the decrease in Ca content, as mentioned earlier. Hardness, cohesiveness, and gumminess correlated negatively with $\mathrm{K}$ and $\mathrm{Na}$, whereas adhesiveness showed a positive correlation with $\mathrm{K}$ and $\mathrm{Na}$. The negative correlation of $\mathrm{Na}$ and $\mathrm{K}$ versus the positive correlation of Ca with hardness, cohesiveness, and gumminess may be due to $\mathrm{Na}$ or $\mathrm{K}-\mathrm{Ca}$ ion exchange. Guinee and Fox (2004) reported that the addition of $\mathrm{NaCl}$ led to $\mathrm{Na}-\mathrm{Ca}$ ion exchange with paracasein. In our study, ion 
exchange may have occurred between $\mathrm{Ca}$ and $\mathrm{Na}$ or $\mathrm{K}$; therefore, the correlations of these elements with texture profile parameters were contradictory.

\section{CONCLUSIONS}

The partial substitution of $\mathrm{NaCl}$ with $\mathrm{KCl}$ appears to result in a similar texture profile and microstructure of Halloumi cheese compared with those of the control (only $\mathrm{NaCl}$ ). Hardness, cohesiveness, adhesiveness, and gumminess of Halloumi cheeses kept in $\mathrm{NaCl} / \mathrm{KCl}$ brine solution were similar to those stored in $\mathrm{NaCl}$ only. Calcium played a major role in influencing the texture profile.

\section{REFERENCES}

Abd El-Salam, M. H., and E. Alichanidis. 2004. Cheese varieties ripened in brine. Pages 227-249 in Cheese: Chemistry, Physics and Microbiology: Vol. 2: Major Cheese Groups. 3rd ed. P. F. Fox, P. L. H. McSweeney, T. M. Cogan, and T. P. Guinee, ed. Elsevier Academic Press, London, UK.

Alichanidis, E., and A. Polychroniadou. 2008. Characteristics of major traditional regional cheese varieties of East-Mediterranean countries: A review. Dairy Sci. Technol. 88:495-510.

Anifantakis, E. M., and S. E. Kaminarides. 1983. Contribution to the study of Halloumi cheese made from sheep's milk. Aust. J. Dairy Technol. 38:29-31.

AOAC International. 1995. Official Methods of Analysis of AOAC International. 15th ed. AOAC International, Arlington, VA.

Ayyash, M. M., and N. P. Shah. 2010. Effect of partial substitution of $\mathrm{NaCl}$ with $\mathrm{KCl}$ on Halloumi cheese during storage: Chemical composition, lactic bacterial count, and organic acids production. J. Food Sci. 75:C525-C529.

Bhaskaracharya, R. K., and N. P. Shah. 1999. Texture evaluation of commercial mozzarella cheeses. Aust. J. Dairy Technol. 54:3640.

Bhaskaracharya, R. K., and N. P. Shah. 2000. Texture characteristics and microstructure of skim milk mozzarella cheeses made using exopolysaccharide or non-exopolysaccharide producing starter cultures. Aust. J. Dairy Technol. 55:132-138.

Cichoscki, A. J., E. Valduga, A. T. Valduga, M. E. Tornadijo, and J. M. Fresno. 2002. Characterization of Prato cheese, a Brazilian semi-hard cow variety: Evolution of physico-chemical parameters and mineral composition during ripening. Food Contr. 13:329336.

Fitzgerald, E., and J. Buckley. 1985. Effect of total and partial substitution of sodium chloride on the quality of Cheddar cheese. J. Dairy Sci. 68:3127-3134.

Forshee, R. A. 2008. Innovative regulatory approaches to reduce sodium consumption: Could a cap-and-trade system work? Nutr. Rev. 66:280-285.

Fox, P. F., and P. L. H. McSweeney. 1996. Proteolysis in cheese during ripening. Food Rev. Int. 12:457-509.

Guinee, T. P. 2004. Scrap the salt: As concern about the high salt content of cheese rises, Dr T. P. Guinee looks at ways of keeping it as low as possible. Dairy Ind. Int. 69:36-38.

Guinee, T. P., E. P. Feeney, M. A. Auty, and P. F. Fox. 2002. Effect of $\mathrm{pH}$ and calcium concentration on some textural and functional properties of mozzarella cheese. J. Dairy Sci. 85:1655-1669.

Guinee, T. P., and P. F. Fox. 2004. Salt in cheese: Physical, chemical and biological aspects. Pages 207-259 in Cheese: Chemistry, Physics and Microbiology: Vol. 1: General Aspects. 3rd ed. P. F. Fox, P. L. H. McSweeney, T. M. Cogan, and T. P. Guinee, ed. Elsevier Academic Press, London, UK.
Heaney, R. P. 2006. Role of dietary sodium in osteoporosis. J. Am. Coll. Nutr. 25(3. Suppl):271S-276S

Johnson, M. E., R. Kapoor, D. J. McMahon, D. R. McCoy, and R. G. Narasimmon. 2009. Reduction of sodium and fat levels in natural and processed cheeses: Scientific and technological aspects. Compr. Rev. Food Sci. Food Saf. 8:252-268.

Joshi, N. S., K. Muthukumarappan, and R. I. Dave. 2003. Understanding the role of calcium in functionality of part skim mozzarella cheese. J. Dairy Sci. 86:1918-1926.

Kaminarides, S., P. Stamou, and T. Massouras. 2007. Changes of organic acids, volatile aroma compounds and sensory characteristics of Halloumi cheese kept in brine. Food Chem. 100:219-225.

Kaplan, N. M. 2000. The dietary guideline for sodium: Should we shake it up? No. Am. J. Clin. Nutr. 71:1020-1026.

Katsiari, M. C., and L. P. Voutsinas. 1994a. Manufacture of low-fat Feta cheese. Food Chem. 49:53-60.

Katsiari, M. C., and L. P. Voutsinas. 1994b. Manufacture of low-fat Kefalograviera cheese. Int. Dairy J. 4:533-553.

Katsiari, M. C., L. P. Voutsinas, E. Alichanidis, and I. G. Roussis. 1997. Reduction of sodium content in Feta cheese by partial substitution of $\mathrm{NaCl}$ by KCl. Int. Dairy J. 7:465-472.

Katsiari, M. C., L. P. Voutsinas, E. Alichanidis, and I. G. Roussis. 1998. Manufacture of Kefalograviera cheese with less sodium by partial replacement of $\mathrm{NaCl}$ with $\mathrm{KCl}$. Food Chem. 61:63-70.

Lemann, J. Jr., J. A. Pleuss, and R. W. Gray. 1993. Potassium causes calcium retention in healthy adults. J. Nutr. 123:1623-1626.

Massey, L. K. 2005. Effect of dietary salt intake on circadian calcium metabolism, bone turnover, and calcium oxalate kidney stone risk in postmenopausal women. Nutr. Res. 25:891-903.

Massey, L. K., and S. J. Whiting. 1995. Dietary salt, urinary calcium, and kidney stone risk. Nutr. Rev. 53:131-139.

Papademas, P., and R. K. Robinson. 2001. The sensory characteristics of different types of Halloumi cheese as perceived by tasters of different ages. Int. J. Dairy Technol. 54:94-99.

Petik, S. 1987. Reduced sodium cultured dairy products. Cult. Dairy Prod. J. 22:12-14

Pons, M., and S. M. Fiszman. 1996. Instrumental texture profile analysis with particular reference to gelled systems. J. Texture Stud. 27:597-624.

Reddy, K. A., and E. H. Marth. 1991. Reducing the sodium content of foods: A review. J. Food Prot. 54:138-150.

Reddy, K. A., and E. H. Marth. 1993. Composition of Cheddar cheese made with sodium chloride and potassium chloride either singly or as mixtures. J. Food Compost. Anal. 6:354-363.

Robinson, R. K. 1991. Halloumi cheese-The product and its manufacture. Pages 144-158 in Feta and Related Cheeses. R. K. Robinson and A. Y. Tamime, ed. Ellis Horwood Ltd., London, UK.

SAS Institute. 2008. SAS/STAT 9.2 User's Guide. SAS Institute Inc., Cary, NC.

Shank, F. R., Y. K. Park, B. F. Harland, J. E. Vanderveen, A. L. Forbes, and L. Prosky. 1982. Perspective of food and drug administration on dietary sodium. J. Am. Diet. Assoc. 80:29-35.

Sihufe, G. A., S. E. Zorrilla, and A. C. Rubiolo. 2006. Secondary proteolysis of Fynbo cheese salted with $\mathrm{NaCl} / \mathrm{KCl}$ brine and ripened at various temperatures. Food Chem. 96:297-303.

Tamime, A. Y. 2006. Brined Cheeses. Society of Dairy Technology book series. Blackwell Publishing Ltd., Oxford, UK.

Taylor, D. L. 1983. New option to produce low-sodium cheese. Food Eng. 55:50-51.

Upadhyay, V. K., P. L. H. McSweeney, A. A. A. Magboul, and P. F. Fox. 2004. Proteolysis in cheese during ripening. Pages 391-433 in Cheese: Chemistry, Physics and Microbiology: Vol. 1: General Aspects. $3^{\text {rd }}$ ed. P. F. Fox, P. L. H. McSweeney, T. M. Cogan, and T. P. Guinee, ed. Elsevier Academic Press, London, UK.

Zaki, N. 1990. Effect of salt ratio and starter addition on the microstructure and rheological properties of Domiati cheese. Indian J. Dairy Sci. 43:582-587.

Zorrilla, S. E., and A. C. Rubiolo. 1994. Fynbo cheese $\mathrm{NaCl}$ and $\mathrm{KCl}$ changes during ripening. J. Food Sci. 59:972-975. 